\title{
Illegal Mining and Sustainability Performance: Evidence from Ashanti Region, Ghana
}

\author{
${ }^{1}$ Thomas Nti ${ }^{*},{ }^{2}$ YinFei Chen, ${ }^{3}$ Bright Parker Quayson, ${ }^{4}$ Fred Yeboah Agyei \\ ${ }^{1,2,3}$ School of Finance and Economics, Jiangsu University, P.R. China, 212013 \\ ${ }^{4}$ Department of Forestry Science, University of Energy and Natural Resources, Sunyani, Ghana
}

\begin{abstract}
The As illegal mining in Ghana has become increasingly rampant ever, this study aimed at examining the effect of illegal mining on the dimensions of sustainability performance among crop farmers and the challenges they face because of illegal mining in the Ashanti Region, Ghana.

To investigate the intriguing connections among illegal mining and sustainability performance among crop farmers, this paper draws on multidisciplinary literature and collects empirical data from 250 respondents in the Atwima Nwabiagya and Atwima Mponua Districts, Ghana to test the proposed model and hypotheses using structural equation modeling.

All three (3) elements or paradigms of sustainability performance were negatively affected by illegal mining activities. It was also observed that a significant positive relationship exists among all the elements of sustainability performance hence a consequence on one element may affect the other.

Unlike most research on illegal mining that has been theoretical, this study represents one of the few empirical analyses of how illegal mining may affect sustainability performance.
\end{abstract}

Keywords: Illegal Mining, sustainability performance, confirmatory factor analysis (CFA)

\section{Introduction}

Illegal mining as an activity undertaken without state approval in places like game reserves, forest reserves and or near water bodies even with a mining license Illegal [1]. Illegal mining in Ghana over the years has been on the rise in many areas of the country because of its appealing nature [2] to the neglect of its negative impacts on the citizenry. About 20 million people worldwide engage in illegal mining and contribute almost one-fourth of the world's gold output [3].

There are about 300,000-500,000 illegal miners in Ghana and their total contribution to GDP amounts to $\$ 461.1$ million since 1989 [4]. [5] observed that illegal mining could be a tool to reduce poverty but at the same time bring negative impacts on its environments underscoring urgent intervention from the government and the citizens at large to pursue sustainability.

According to [6], the greater contributions of mining revenue comes from small scale miners who are mostly illegal. Consequently, illegal mining activities can generate social, environmental and economic impacts [7] [8] and this has increasingly gotten attention from the Ghana government by bringing into effect the interministerial task force popularly known as operation vanguard by the public to help curb or eradicate the problems. Given the contributions and the effects of illegal mining, the need for improvement in sustainable performance is a vital aim for both industry and the economy at large [9].

Several Sustainable Development Goals (SDGs) by the United Nations for 2030 will be in doubt without substantial contributions from the mining sector which serves as raw materials for the manufacturing sector to create employment and valued addition along the supply chains of material goods [10]. Additionally, the bid to boost the production of mineral raw materials can cause social, environmental and economic impacts, which can also compromise the goals of other sustainable development targets.

Resource use can cause either positive, negative or both impacts in communities with these resources which 
is evident in the scholarly debate on the "resource curse" hypothesis which postulates that countries blessed with natural resources tend to have a slower growth rate than resource-poor countries [11].

Many researchers from different fields have recently made enormous contributions to the literature on illegal mining [12][13][14][15]; the sustainability aspect has received little attention [16]. Sustainability is a calculated approach to meet the desires of the current generation without affecting the prospects of yet unborn ones to secure their future [17] which uses the Tripod-Bottom Line concept-environmental conservation, social responsibility, and economic development.

Sustainability is essential to curb the negative repercussions left by illegal mining on its vicinity hence many institutions including governments are looking for ways to ensure sustainable programs to mitigate social and environmental issues not forgetting the minerals industry through the Global Mining Initiative [18].

The government and its agencies also need to pursue sustainability in its combat of illegal mining since it is essential for achieving environmental quality to have clean air, natural resources, and a non-toxic environment. Additionally, sustainability determines the state of our health largely because our environment affects our health directly.

According to [19], deforestation and land degradation end up in some $18 \%$ of world carbonic dioxide emissions. [20] Observed that most of our natural resources are shrinking because of logging, illegal mining activities and other developmental issues. Ministry of Lands and Natural Resources, Ghana 2012 [21] puts the rate of deforestation at $2.0 \%$ which results in a yearly loss of about 135.000 ha. Prospective small-scale miners can apply for a license but the process is cumbersome due to bureaucratic processes which makes illegal mining activity more appealing [22].

The government has created complex regulatory environmental regulations procedurally, but unsuccessful in the area of on-site support and extension services [23] to curb the negative effects of illegal mining activities. Currently, there is limited research work on illegal mining and sustainability hence the study aims at looking at activities of illegal mining and sustainable performance of farmers.

\section{Conceptual framework and hypotheses development}

\subsection{Illegal mining}

According to [24], illegal miners are seen as ' threatening, " danger, " threat, " headache, " challenge ' and ' a problem, ' which need a strategic and comprehensive solution to combat with accompanying sustainable practices. The government sees illegal mining as a blockade of the future economy [24] in dealing with the nuisance [24]. The day-to-day activities of illegal miners are considered destructive to the environment, the social setting and the economy in general by development agencies thus illegal activities largely have longterm negative impacts on its actors and the economy at large. Most often, illegal miners engage in fierce confrontations with landowners and large-scale foreign miners [22].

Illegal mining is inversely related to a low level of education and directly related to high unemployment rates in developing countries [12]. Rural households make bread and butter choices based on natural resources (land, water, forest resources), social capital (interpersonal networks, team membership, and association), human capital (education, skills, health), physical capital (irrigation channels, equipment, roads), and money capital (cash, savings, and cattle). How to and the means to amass these capital form a household's resource methods and the relationship it has with the environment [25] [26]. For instance, households with high educational background and low endowments of natural capital (land and forest) are more likely to earn their sustenance from nonfarm work as a way of both coping with natural resource scarcity to get the highest returns from education. On the other hand, households with little educational background and a high natural capital base (forest) are more likely to earn a living from mining goods because they lack the skills and resources to diversify their sources of income [27].

Besides, decisions on livelihoods are determined by many contextual factors, including structural factors (market working, land tenure systems, common property regimes), cultural factors (gender roles, spiritual land association), fiscal factors (local and international demand for locally produced goods) and environmental changes (climate change) [28]. This menace has caused greater depletion of the land and its uses have caused a huge change in the cropland and crop production [29]. Illegal gold operations are located on fertile agricultural lands in rural areas, which have caused prevalent ecological degradation [30][31]. It 
has been shown to harm agriculture with effects such as pollution, land grabbing having a direct impact on rural income and living [32][33]. The activities of illegal miners pose a danger to the lands used for agriculture because it has affected farmlands and rendered food insecurity in most family units in the communities [34].

In most cases, logging and clearing of the surface soil have caused agricultural degradation, soil erosion, water bodies' contamination, and aquatic life. Their activities culminated in heavy machinery land depletion, resulting in nutrient loss and soil fertility for farming purposes[35]. Mining operations are generally carried out where agricultural activities are typically dominant and the spillage of chemicals such as cyanide and mercury affects crops and health risks to farmers, leading to unproductive farmland and moving farmers from sustainable livelihoods to alternative income-generating enterprises. [36][37].

\subsection{Sustainable performance}

The notion of sustainable performance and development is a widely used term in many areas of activity related to the lifetime of a person. There has been a broad concern for the requirement towards mounting tools to translate the thought and goals of sustainability into real action and into measures to judge progress towards them. Most researchers have paid an excessive amount of attention to coverage instead of the impact numerous human activities are having on sustainable performance and development. The aim of achieving sustainability is growth that meets the needs of this generation whereas not undermining the potential of future generations to satisfy their wishes (Towards Sustainable Mining-TSM, 2019)[38][39]. This means that each of the paradigms that make up the sustainability performance defines the community obligations of companies to improve social, economic including environmental performance. The International Council of Mines and Metals [40] therefore outlines that sustainable development framework includes an undertaking by miners to add to the social, economic and environmental advancement in areas where miners operate [40]

Despite the dynamic economic growth of the countries blessed with natural resources, control of these resources is essential [41] to ensure sustainability. Fundamental to sustainable performance dimension is the use of performance indicators to capture and fuse information about the 3 key areas involved, namely Social, environmental and economic [42][43]; social, meaning care for the farmers and even the illegal miners at their workplace and community development

$>$ ecological, ensuring the protection of natural resources and the environment in the face of illegal mining activity

$>$ procedural and ec'onomic activities safeguarding economic growth

According to [43], social responsibility means ensuring the workplace is safe for all economic actors for working which includes the social aspects of mining, including but not limited to the families of miners and the environment.

Economic growth means realizing long-run sustainability concerning each planned production volumes and achieving economic efficiency obtained from the sale of the mined minerals [43]. Protection of natural resources and the environment means concern for the layer and the protection of its resources by its rational acquisition, characterized by savings in its depletion [43]. Thus, government and citizens alike should take steps to reduce the negative impacts on the environment by illegal mining hence pursuing sustainability. 

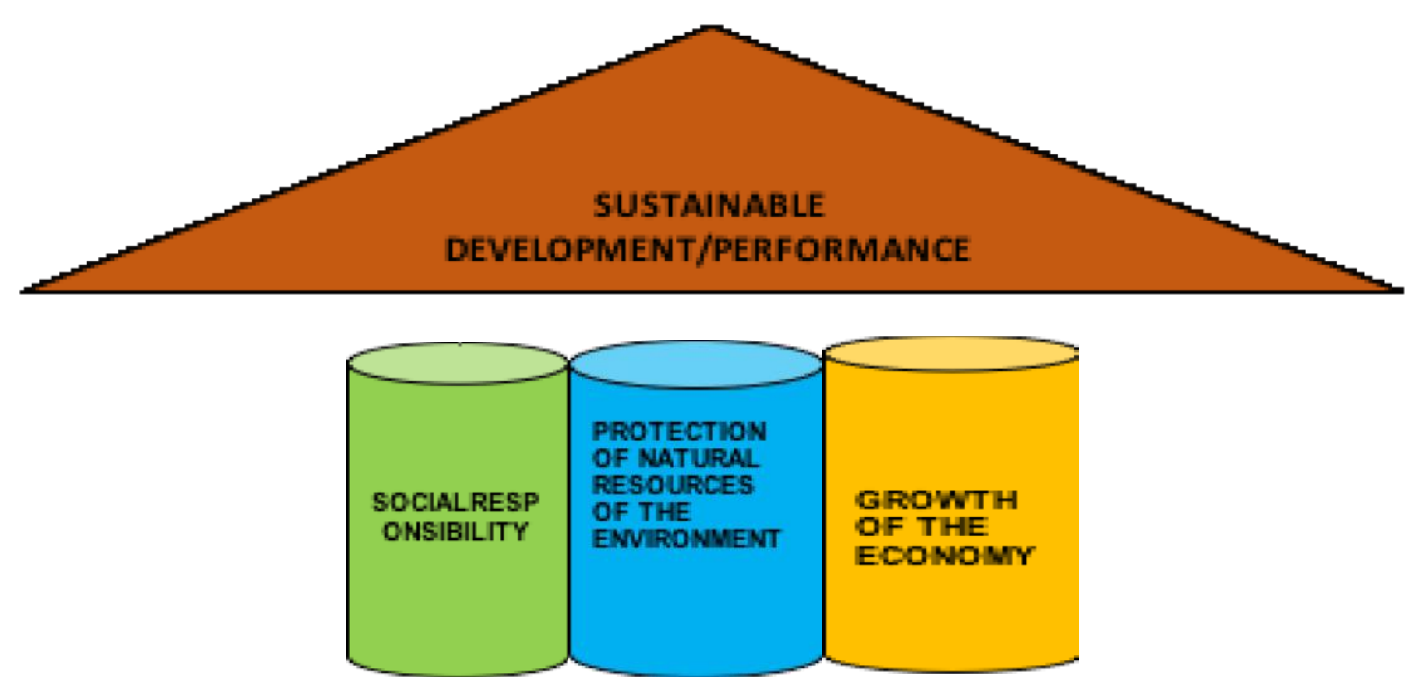

Fig1. Elements that create the terms of sustainable Performance

According to the [44] presently under development for measuring mining company performances in terms of social, environmental and economic practices, there is the need to include efforts towards contributing to SDGs. Sustainable performance is a continuing process and not a temporary undertaking. It has clearly defined goals and recommended ways of achieving them in all of the preceding key areas [45].

\subsubsection{Social Elements}

The social orientation of every society is guided by the long stand for certain norms and customs. The concentration of illegal mining activities negatively impacted society and its cultural values and practices such as prostitution, drug abuse, inadequate housing, and school dropouts is because of the rise of illegal mining in most mining areas [46]. [30] postulates that over the last two decades, communities on the tassels of large-scale mining projects have been subjected to the increasing use of intimidation, abuse, violence, and violations of human rights by mining companies and state security agencies, including forceful evictions, arbitrary arrests, illegal detention, the demolition or burning of villages, beatings, shootings, dog attacks, rape, and murder. Sometimes extreme poverty, illiteracy and the low consciousness that mining communities have about their rights have provided grounds for the violation of the rights of communities by these mining companies and state securities.

\subsubsection{Environmental Elements}

Activities of illegal miners and its consequences are degrading to the land and other resources significantly. Illegal mining activities account for the reduced rain forest and rich topsoil for cultivation coupled with deforestation and the generating of waste [47].

Another devastating effect from this menace is water contamination due to the addition of large amounts of materials to the water from illegal mining activities hence not good for human use [48]. The rise of illegal mining companies has resulted in stream toxic waste from cyanide spillages, acid extract drainage, tailings leakages, mine waste disposal, and mine pits. They do not follow environmental standards, as a result, they release a harmful substance that finds its way into water bodies, and contaminate it.

Minerals extraction from the soil irrespective of the technique adopted results in the destruction of the landscape without due process. Illegal miners have cleared some places known to be forest reserve to accommodate surface mining by illegal miners [48]. This practice has led to the removal of large quantities of topsoil, leaving the land bare and susceptible to erosion. The elimination of the topsoil often renders the land practically incapable of supporting crop farming

\subsubsection{Economic Elements}

The mining sector is a significant contributor to formal and informal employment in countries that have gold and other ores. [49] Claimed that approximately, 20,000 people are employed in large-scale mining whilst 500,000 people are employed in the small-scale sector. The mining industry also generates revenue for the 
internal economy through salaries, wages and other payments made to employees, contractors, and taxes on salaries of employees, and social security contributions from employees and their employers. Communities, where the activities of these mining take place, do not often benefit from investment opportunities, employment, and royalties paid to them and other accompanying settlements [49].

Despite the benefits that a country generates from the mining industry, the negative effects of illegal mining cannot be understated. One of the known negative effects of illegal mining within a community is the high cost of living. Communities near mines experience the outrageously high cost of living in every aspect of their daily life expenditures; there is a high price tag beyond the reach of an average person including food, accommodation, health, water [34]. This makes life a hectic one for the average person in the community. The factors responsible for the high cost of living in mining communities are usually a result of the disparities in income which usually favors the top hierarchy [34]. Again, illegal mining has withdrawn a significant percentage of the labor force from agriculture in these communities and other income-generating activities by taking farmland away and holding out the false promise of revenue. The fall in food production in some illegal mining communities with a relatively high population and high unemployment accounts for high food prices.

\subsection{Illegal mining versus resource abundance}

The resource abundance theory postulates that countries particularly Less Developed ones endowed with natural resources tend to have high rates of poverty. It stresses that the abundance of minerals and fuel in less developed countries (LDC) contribute to come up with negative developmental outcomes as well as poor economic performance, growth collapse, high levels of corruption and ineffective governance [50]. Naturally, resource gifted countries experience bad or worse economic and political outcomes than countries with no endowment [51]. The rationale behind this phenomenon resulted from a variety of reasons such as Dutch disease, rent-seeking, crowding out of human capital and crowding out of social capital The Dutch disease is an economic concept coined in 1960 in the Netherlands. It denotes the potential negative effects natural resource windfalls and accompanying appreciations of the exchange rate can have on the entire economy for instance potential dangers of oil booms[50].

While it may be expected to see better development outcomes after countries discover natural resources, resource-rich countries tend to have higher rates of conflict and authoritarianism, and lower rates of economic stability and economic growth, compared to their non-resource-rich neighbors[53]. The unfavorable effects of natural resources on the economy can be emphasized through two perspectives: a market-based viewpoint focusing on macroeconomic mechanisms and a political economy approach stressing the role and effectiveness of institutions [54] [53]. While there are numerous challenges unique to mineral extractions, governments of such countries can make policy decisions that can help avoid some of the negative consequences of these extractions and maximize the benefits. This study uses the tenets of the resource curse theory to identify how well-endowed resource can be a swearword. The target areas for this study may not be an exception.

[55] investigated the socio-economic and environmental influences of mining on immediate communities around Borini Porono quarry in Kogi State, central Nigeria and found out that the mining activities have resulted in cracking of buildings; pollution of various kinds (air, noise, and land) to the environment. [55] Recommended the government need to make it mandatory for mining companies at both large and smallscale not to mention illegal miners, to submit environmental impact assessment.

Again, [56] examined the effect that artisanal mining has on the poor rural agricultural communities with purposive sampling and data analyzed and concluded that it has attracted able-bodied labor from irrigation farming to join the artisanal mining activity thereby decreasing the productive capacity of the irrigation scheme.

[57] Explored the effects of illegal mining on crop production in the Amansei Central district of Ghana and said that the illegal mining business has attracted many able-bodied men causing a reduction in productivity and water pollution. He concluded that there should be political and communal wills to eradicate illegal mining otherwise known as galamsey activities in rural communities of Ghana.

[58] conducted a study on mining activities in Prestea in the western region of Ghana and found out that galamsey deplete environmental resources such as water, soil, the landscape, vegetation, the ecosystem, 
among others and left many major rivers in the region heavily polluted.

Fig 2: The research model

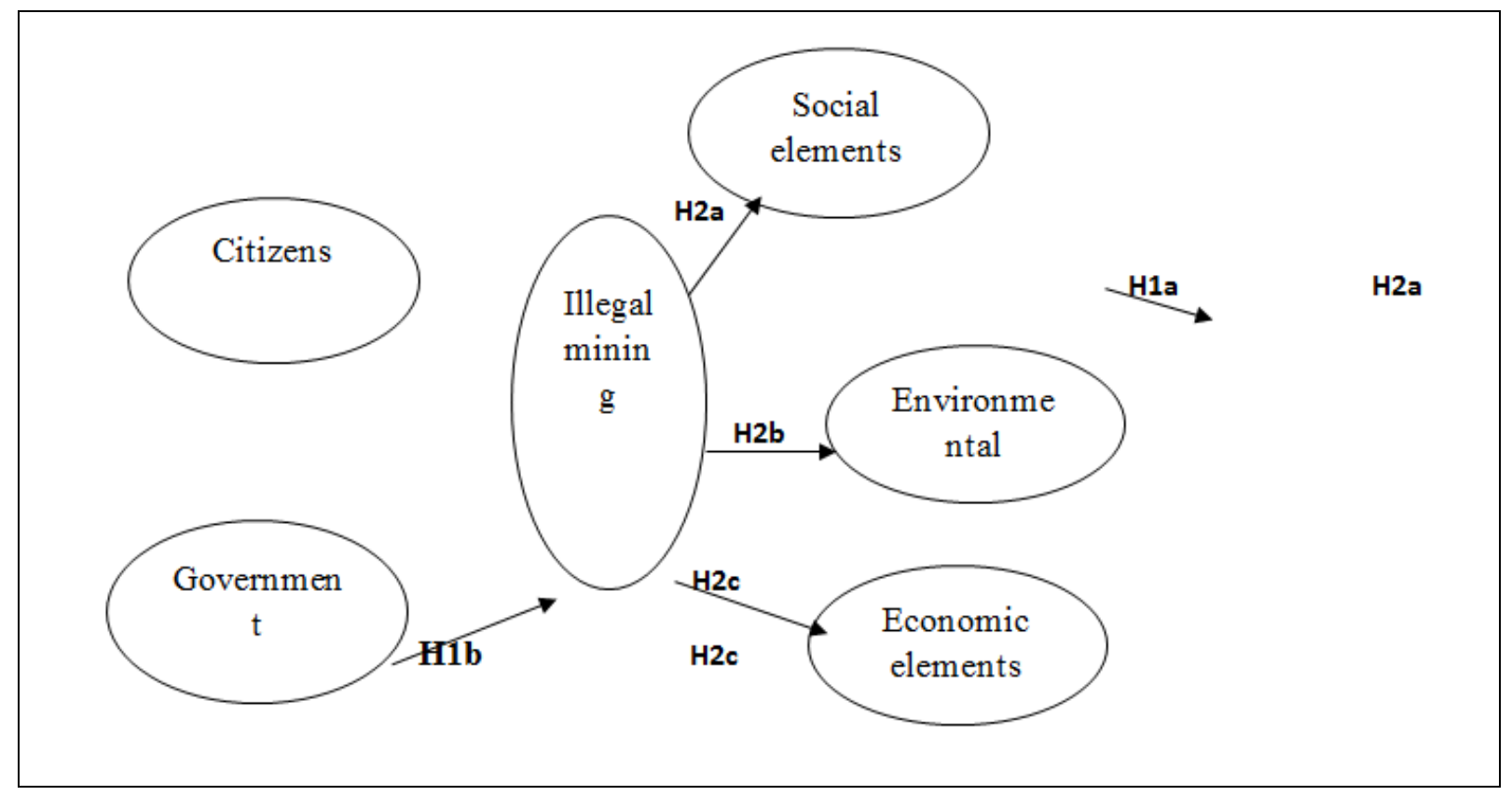

Hypotheses

From the literature, people with zero income can smoothen consumption through borrowing, stealing, receiving alms and will be prepared to engage in whatever activity irrespective of its outcome [59][60][61].

Government and its agencies brand illegal mining as evil and detractors to development but those agencies grant concessions to these illegal miners and even go to the extent of providing security for these miners [62]. We, therefore, hypothesized that:

H1a: Citizens activities are positively related to illegal mining

H1b: Government activities are positively related to illegal mining

Governments and Citizens activities alike complement each other in the illegal mining business that has a telling effect on social, environmental and economic elements of sustainable performance [63]. We, therefore, posit that:

H2a: Illegal mining has a negative effect on the social elements of sustainable performance

$\mathrm{H} 2 \mathrm{~b}$ : Illegal mining has a negative influence on the environmental elements of sustainable performance

$\mathrm{H} 2 \mathrm{c}$ : Illegal mining has a negative effect on the economic elements of sustainable performance

\section{Methodology}

\subsection{Description of the study area}

The Atwima Mponua and the Atwima Nwabiagya Districts are two of the 254 Metropolitan, Municipal and District Assemblies (MMDAs) in Ghana, and forms part of the 43 of MMDAs in the Ashanti Region with Nyinahin as its Administrative capital [64]. 


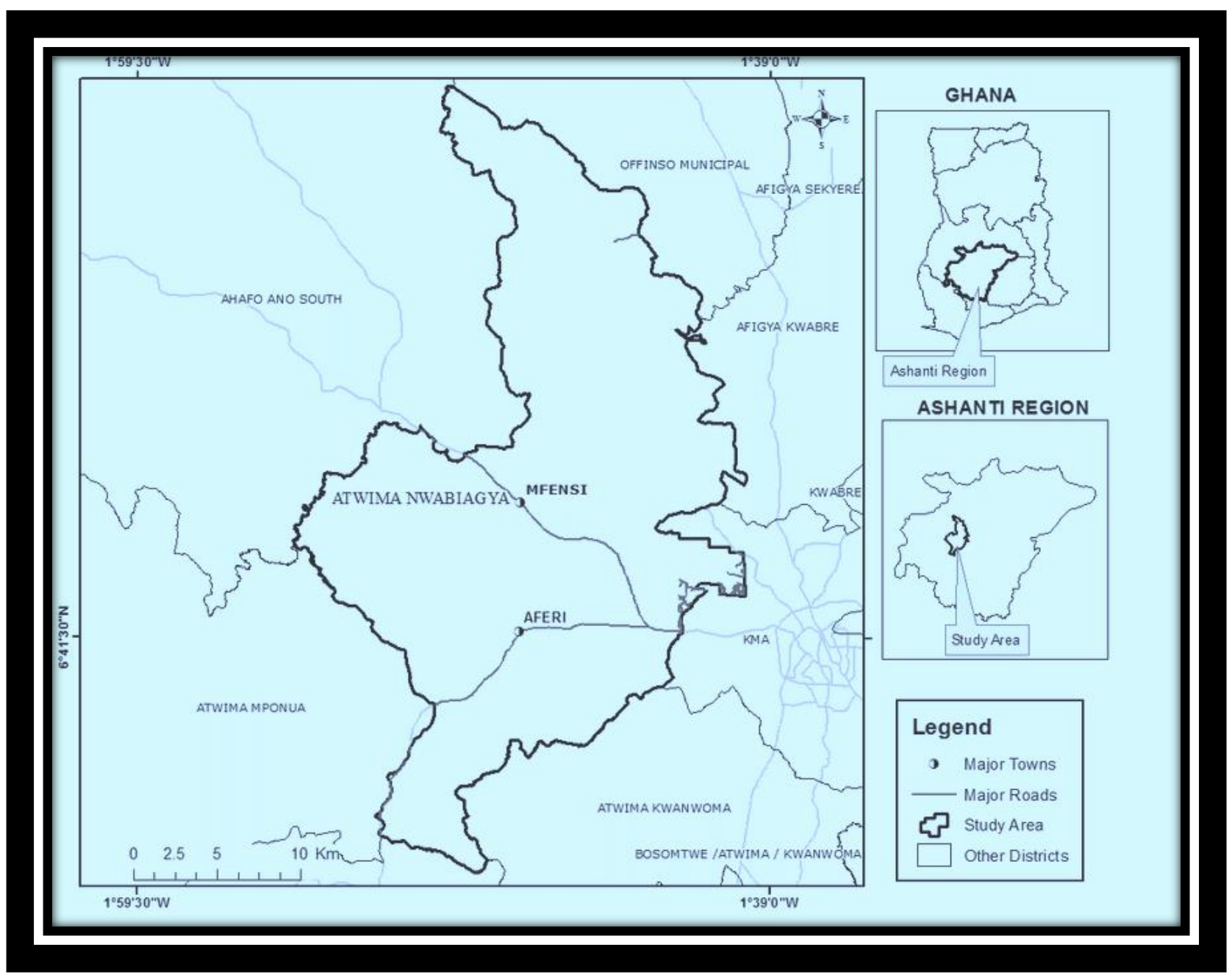

\section{Fig 3: Geographical map of Atwima Mponua District}

The district is located in the southwestern part of the Ashanti Region and lies between longitude 2o00'W and $2032^{\prime} \mathrm{W}$ and latitude $6032^{\prime} \mathrm{N}$ and $6075^{\prime} \mathrm{N}$ covering a land area of 1,883.2 square kilometers. According to [64], persons of 15 years and older by occupations shows that workers in agricultural farming, forestry, and fishing constitute the largest occupational group of about $79.0 \%$ in the district. The Atwima Mponua District is predominantly agrarian like most rural Districts in Ghana. Most of the population is into Agriculture, followed by Commerce, Manufacturing, and Service. For agriculture, there are three main types of crop farming practices in the District namely; mono-cropping, mixed cropping, and plantation cropping. The primary occupation of the people in the district is farming [64].

\subsection{Data, sampling technique, and sample size}

The study used primary data, which was a cross-sectional study on 250 randomly selected household heads. A prototype questionnaire from existing literature on the impact of mining on the sustainability performance of farmers was adapted to gather information on household demographic characteristics. Additionally, an independent section collected information on illegal operations, which makes this dataset useful for this study.

Households were chosen using a two-stage sampling method. First, two districts in the region were selected following the criteria of 1) the community is a place where illegal mining activities are practiced; 2) where the majority of the people in the district are crop farmers.

In the second stage, households were randomly selected from a list including all the households in the community, which was provided by community leaders. 250 persons were interviewed and asked to respond to the structured questionnaire. 
Table 1: Selected Communities and Sample size

\begin{tabular}{|l|c|}
\hline District or Community & Sample size \\
\hline Atwima Nwabiagya & 125 \\
\hline Atwima Mponua district & 125 \\
\hline Total & 250 \\
\hline
\end{tabular}

Source: Author's computation (2019)

3.3 Investigate the influence of illegal mining on sustainability performance in mining communities After data collection, data analysis was performed to examine the postulated model and its paths. Illegal mining is deemed to have an impact on sustainability performance as a dependent variable, which is made up of three elements: Social, environmental and economic elements. Confirmatory factor analysis (CFA) was used to reach an adequate fit factor structure for the measurement model. Structural Equation Modeling (SEM) technique was used to analyze the hypothesized structure. The aim was to investigate the impact of illegal mining on these elements of sustainability performance.

\section{Table 2: Reliability Indicators}

\begin{tabular}{|l|l|l|}
\hline Variables & No. of Items & Cronbach Alpha \\
\hline Illegal mining & 4 & .725 \\
\hline Social Element & 4 & .866 \\
\hline Environmental Element & 5 & .804 \\
\hline Economic Element & 4 & .774 \\
\hline & 17 & \\
\hline
\end{tabular}

Source: Field data (2019)

The reliability coefficients in table 2 for illegal mining, social element, Environmental element, and Economic elements are $.725, .866, .804$ and .774 respectively, with all Cronbach alpha values higher than .70 , indicating the high internal consistency of each scale instrument.

\section{Data Analysis and Discussions}

Per results as presented in table 3 , it is evident that out of the 250 respondents who completed the survey questionnaire through interviews, 77 of them were women representing $30.8 \%$ whilst 173 of them were men representing $69.2 \%$. It is however clear that the majority of respondents to this survey were men, those between the age group of 18-34 were the majority with 51.6\% while those less than 18 were the lowest with $6.8 \%$. This adds to other reports that men constitute the general active agricultural working force (particularly crop farming) and that of the mining sector. On the educational level, the majority of the respondents were having secondary education (S.H.S and vocational) representing $44.8 \%$, followed by Basic education (primary and J.H.S) with $30.8 \%$ and those with tertiary qualification being the least with $24.4 \%$ as shown in table 3 . This adds to other reports that men constitute the general active agricultural working force (particularly crop farming) and that of the mining sector. Most of the respondents were Ghanaians representing $94.0 \%$ whereas $6.0 \%$ were foreigners. $64.2 \%$ of the respondents have stayed in this community for 6 years and over whereas $37.6 \%$ of the respondents have resided in the same community for $0-5$ years, which affirms their responses, are accurate or near accurate. Most of the respondents were household heads with $68.4 \%$ being household heads and $31.6 \%$ being dependents. Most of the respondents indicated they were engaged in some sort of occupation ranging from crop farming-34.4\%, livestock farming-5.6\%, hunting-3.6\%, mining-8.0\% with others representing 48.4\%. Most of the respondents showed that their alternative source of livelihood was illegal mining (galamsey) with $72.4 \%$ followed by gifts from friends and relatives, $18.8 \%$; borrowing, $8.0 \%$ and begging, $0.8 \%$. Most respondents indicated that $3-5$ persons made up their household representing 56.8\% with respondents who indicated 9 and above persons in their household as the least with $3.6 \%$. Again, respondents with less than 10 acres farm size were $54.8 \%$ but respondents with 10 acres and above farm size were $45.2 \%$, which suggests that most of the respondents prefer to keep 
quite a small farm size. More so, the estimated output (0-1000) bags represented $86 \%$ whereas 1001 bags and above represented $14.0 \%$. A detail of the demographic information is given in the table above.

\begin{tabular}{|l|c|c|}
\hline Participate in illegal mining & Frequency & Percentage \\
\hline Yes & 218 & $87.2 \%$ \\
\hline No & 32 & $12.8 \%$ \\
\hline
\end{tabular}

Table 4: Statistics on Respondents participation in Illegal Mining

The majority of the respondents, 168 out of 250 indicated that they are negatively affected by illegal mining activities on their crop farmlands representing $67.2 \%$ whilst 82 respondents $(32.8 \%)$ indicated they are positively impacted by illegal mining from table 4 . Results presented in Table 4 show asymptotically that cocoa, which is the highest cash crop of the country, was affected mostly by illegal mining operations followed by cassava farms. It is assumed that most farmers lost their source of income since these are traditional crops that most farmers grow in these areas.

\subsection{Hypothesis testing}

The structured data on illegal mining and sustainability performance $(N=250)$ were analyzed using SEM. First, an exploratory factor analysis (EFA) was undertaken on the data, then the resulting factor structure was cross-validated using confirmatory factor analysis (CFA). This procedure is routinely adopted, reduces measurement error, creates more accurate SEM models, and allows for greater confidence in the resulting analyses [65][66]. This 2-step process allows for a diagnostic stage, where inaccuracies with the outcome measures can be ironed out, followed by a confirmatory phase, where the latent structure is cross-validated [67]. Following the exploratory and confirmatory factor analyses, model path analysis was used to give a summary of the effect between illegal mining and sustainability performance and its elements.

Table 5: Rotated Factor Loadings

\begin{tabular}{|l|c|c|c|}
\hline \multicolumn{1}{|c|}{ Variables } & Estimate & S.E & C.R label \\
\hline $\begin{array}{l}\text { Respondents level of agreement to the use of one or two excavators } \\
\text { and some other simple tools as an indication of the existence of } \\
\text { illegal mining in the study area }\end{array}$ & 0.827 & 0.101 & 8.18811881 \\
\hline $\begin{array}{l}\text { Respondents level of agreement to mining at dawn or late in the night } \\
\text { as an indication of the existence of illegal mining in the study area }\end{array}$ & 0.712 & 0.123 & 5.78861789 \\
\hline $\begin{array}{l}\text { Respondents level of agreement to mining in unauthorized locations } \\
\text { as an indication of the existence of illegal mining in the study area }\end{array}$ & 0.81 & 0.17 & 4.76470588 \\
\hline $\begin{array}{l}\text { Respondents level of agreement to miners without proper } \\
\text { documents(no license) as an indication of the existence of illegal } \\
\text { mining in the study area }\end{array}$ & 0.514 & 0.108 & 4.75925926 \\
\hline $\begin{array}{l}\text { Respondents level of } \\
\text { secluded environment }\end{array}$ & 0.31 & 0.114 & 2.71929825 \\
\hline $\begin{array}{l}\text { Ragreement to two or more people in a } \\
\text { sustainable performance } \\
\text { performance }\end{array}$ & 0.782 & 0.12 & 6.51666667 \\
\hline Rankings on social effect (large scale corruption) on sustainable & 0.824 & 0.111 & 7.42342342 \\
\hline
\end{tabular}




\begin{tabular}{|c|c|c|c|}
\hline $\begin{array}{l}\text { Rankings on social effects (injuries to life) on sustainable } \\
\text { performance }\end{array}$ & 0.698 & 0.134 & 5.20895522 \\
\hline $\begin{array}{l}\text { Rankings on social effects (theft and drugs) on sustainable } \\
\text { performance }\end{array}$ & 0.598 & 0.185 & 3.23243243 \\
\hline $\begin{array}{l}\text { Rankings on social effects (prostitution, teenage pregnancy, and } \\
\text { school dropouts) on sustainable performance }\end{array}$ & 0.623 & 0.245 & 2.54285714 \\
\hline \multicolumn{4}{|l|}{ Environmental Elements } \\
\hline $\begin{array}{l}\text { Rankings on environmental effects (Water pollution) on sustainable } \\
\text { performance }\end{array}$ & 0.824 & 0.1 & 8.24 \\
\hline $\begin{array}{l}\text { Rankings on environmental effects (Air pollution) on sustainable } \\
\text { performance }\end{array}$ & 0.759 & 0.104 & 7.29807692 \\
\hline $\begin{array}{l}\text { Rankings on environmental effects (Lumbering) on sustainable } \\
\text { performance }\end{array}$ & 0.785 & 0.125 & 6.28 \\
\hline $\begin{array}{l}\text { Rankings on environmental effects (open mining pits) on sustainable } \\
\text { performance }\end{array}$ & 0.636 & 0.211 & 3.01421801 \\
\hline $\begin{array}{l}\text { Rankings on the environmental effect (Land degradation) on } \\
\text { sustainable performance }\end{array}$ & 0.681 & 0.215 & 3.16744186 \\
\hline \multicolumn{4}{|l|}{ Economic Elements } \\
\hline $\begin{array}{l}\text { Rankings on economic effect (employment creation) on sustainable } \\
\text { performance }\end{array}$ & 0.564 & 0.245 & 2.30204082 \\
\hline $\begin{array}{l}\text { Rankings on economic effect (destruction of arable lands) on } \\
\text { sustainable performance }\end{array}$ & 0.644 & 0.208 & 3.09615385 \\
\hline $\begin{array}{l}\text { Rankings on economic effect (high cost of living and fall in output) } \\
\text { on sustainable performance }\end{array}$ & 0.876 & 0.123 & 7.12195122 \\
\hline $\begin{array}{l}\text { Rankings on economic effect (generates income) on sustainable } \\
\text { performance }\end{array}$ & 0.891 & 0.119 & 7.48739496 \\
\hline
\end{tabular}

\section{Source: Field data (2019)}

The items loading on the Factor reflected illegal mining and the elements that made up sustainability performance.

\section{Confirmatory Factor Analysis (CFA)}

CFA was conducted on the items representing illegal mining and sustainability performance: social elements, environmental elements, and economic elements. Fig 6 describes the full model with standardized parameter estimates. 


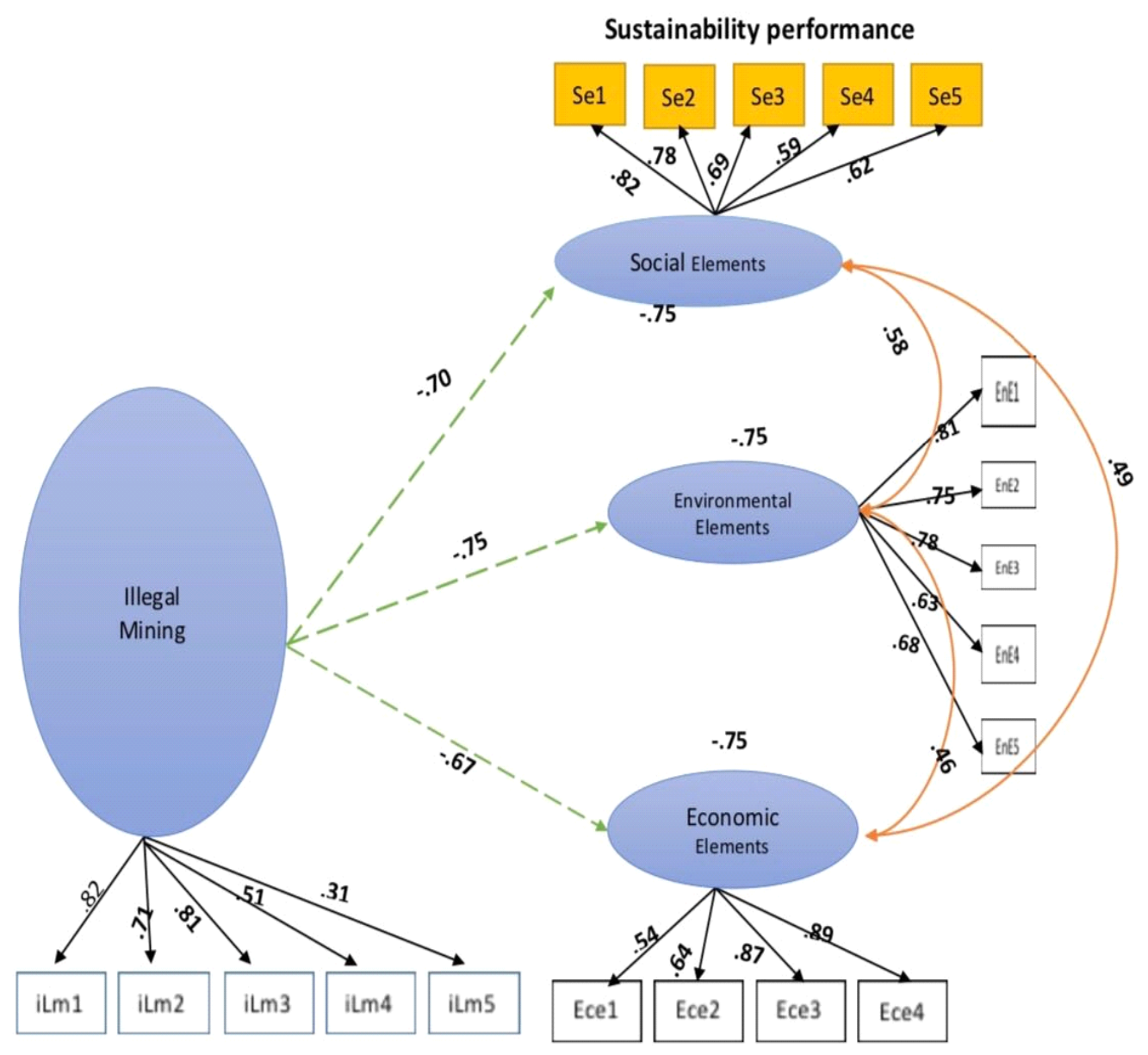

Figure6: Confirmatory factor analysis

Note: ILm = illegal mining, $\mathrm{Se}=$ Social Elements, $\mathrm{EnE}=$ Environmental Elements, Ece $=$ Economic Elements.

ILm1-Level of an agreement to the use of one or two excavators and some other simple tools as an indication of the existence of illegal mining

ILm2- Level of an agreement to mining at dawn or late in the night as an indication of the existence of illegal mining

ILm3- Level of an agreement to mining in unauthorized locations as an indication of the existence of illegal mining

ILm4- Level of an agreement to miners without proper documentation (no license) as an indication of the existence of illegal mining

ILm5-Level of an agreement to two or more people in a secluded environment

Se1-Rankings on social elements (theft and drugs) on sustainable performance

Se2- Rankings on social elements (injuries to life) on sustainable performance

Se3- Rankings on social elements (dispossession of properties) on sustainable performance

Se4- Rankings on social elements (large-scale corruption) on sustainable performance

Se5- Rankings on social elements (prostitution, teenage pregnancy, and school dropouts) on sustainable performance

EnE1- Rankings on environmental elements (water pollution) on sustainable performance

EnE2- Rankings on environmental elements (air pollution) on sustainable performance

EnE3- Rankings on environmental elements (lumbering) on sustainable performance 
EnE4- Rankings on environmental elements (open mining pits) on sustainable performance

EnE5- Rankings on the severe effect of environmental elements (Land degradation) on sustainable performance

Ece1- Rankings on economic elements (generates income) on sustainable performance

Ece2- Rankings on economic elements (high cost of living and fall in output) on sustainable performance

Ece3- Rankings on economic elements (destruction of arable lands) on sustainable performance

Ece4- Rankings on economic elements (employment creation) on sustainable performance

Broken green arrow= effect of Illegal Mining on Social elements, Economic elements and Environmental elements, orange arrow $=$ relationship between variables

In terms of the effect or influence among the latent variables, illegal mining had a significant negative effect on social element of sustainability performance $(\beta=-.360, p<.05, r=-.70)$; illegal mining again was found to have a significantly negative effect on environmental element of sustainability performance $(\beta=-.450$, $p<.05, r=-.75)$. Finally, another significantly negative effect was found between illegal mining and economic element of sustainability performance $(\beta=-.301, p<.05, r=-.67)$. This means that illegal mining had a significant negative effect on all the 3 elements of sustainability performance.

There was a significantly positive relationship among all the elements of sustainability performance. An indication all areas of sustainability performance are of equal importance hence overemphasizing and undervaluing in one area usually leads to a crisis across the entire scheme.

Fig 7: Relationship among elements of sustainability performance

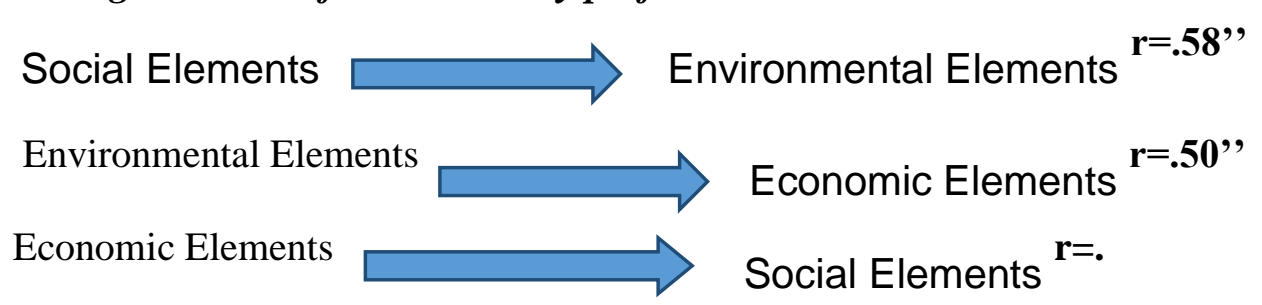

Source: Field survey (2019)

Table 6: Mode Path Analysis Summary

\begin{tabular}{|l|l|l|}
\hline Predictor Variable & Criterion variable & Standard regression \\
\hline Illegal mining & Social Elements & $-.70^{* *}$ \\
\hline Illegal mining & Environmental Elements & $-.75^{* *}$ \\
\hline Illegal mining & Economic Elements & $-.67^{* *}$ \\
\hline Social Elements & Environmental Elements & $.58^{* *}$ \\
\hline Environmental Elements & Economic Elements & $.46^{* *}$ \\
\hline Economic Elements & Social Elements & $.49^{* *}$ \\
\hline & $\mathbf{2}=10.69$ & $\mathrm{DF}=4$ \\
\hline
\end{tabular}

Source: Field survey (2018) ${ }^{*} \mathbf{p}<.10 ; * * \mathbf{p}<.05 ; * * * \mathbf{p}<.01$ 


\begin{tabular}{|c|c|c|c|c|c|c|c|}
\hline \multicolumn{2}{|c|}{ Absolute Fit Level } & \multicolumn{3}{c|}{ Incremental Fit } & \multicolumn{2}{c|}{ Parsimonious Fit Level } \\
\hline $\begin{array}{c}\text { GFI(Goodness } \\
\text { of Fit) }\end{array}$ & RMSEA & RMR & AGFI & CFI & NFI & $\mathrm{X}^{2} / \mathrm{DF}$ & SMC $\left(\mathrm{R}^{2}\right)$ \\
\hline 0.956 & 0.028 & 0.03 & 0.905 & 0.952 & 0.954 & 2.67 & $\begin{array}{c}\text { S.E }=0.251 \\
\text { ENV.E }=0.235 \\
\text { ECO.E }=221\end{array}$ \\
\hline
\end{tabular}

\section{Source: Field survey (2019)}

The model provided a good fit to the data $\left(C F I=0.952, R M S E A=0.028, R M R=0.03, \mathbf{X}^{2} / D F=\right.$ 2.67) suggesting that the predicted model fitted the observed data. The inspection of the standardized residual covariance supported the adequate fit of the model. The squared multiple correlation (SMC) values, which are similar to those in the regression analysis, show that this model accounts for 0.251 of the variances in social elements, 0.235 of the variances in environmental elements and 0.221 of the variances in economic elements of sustainability performance.

\section{Summary of Findings}

1. H1: Illegal mining has a negative influence on the social elements of sustainability performance was accepted.

2. H2: Illegal mining has a negative effect on the environmental elements of sustainability performance was accepted.

3. H3: Illegal mining has a negative impact on the economic elements of sustainability performance was accepted.

\section{Conclusion and Recommendation}

The study on the influence of illegal mining on the sustainability performance of crop farmers in the Ashanti region of Ghana was deemed more relevant for academia and industrial, government and private sector, and grant providing agencies in their policy or strategic implementations. It is concluded from this study that all the elements of sustainability performance were negatively affected by illegal mining activities. It was also observed that a positive relationship exists among all the elements of sustainability performance hence an influence on one element may affect the other. This study suggests the following recommendations for policy implication: The government of Ghana should pay close attention to organizing education at the local government level to inform rural folks who primarily destroy crop farmlands and forests for quick money from illegal mining. Again, there should be a conscious effort towards job creation since the majority of the respondents indicated unemployment as the driving force behind their engagement in illegal mining. Moreover, socio-economic factors including sex, age, educational level, household monthly income and peer influence for illegal mining, and perceived risk in mining should be given keen attention by government and NGOs in the development of any policy framework with the of the aim of addressing illegal mining activities in Ghana.

\section{References}

[1] World Bank Group, “A revised forest strategy for the World Bank Group,” 2002.

[2] R. Bush, "'Soon there will be no-one left to take the corpses to the morgue': Accumulation and abjection in Ghana's mining communities," Resour. Policy, vol. 34, no. 1-2, pp. 57-63, 2009.

[3] G. Hilson, "Putting theory into practice: How has the gold mining industry interpreted the concept of sustainable development?," Miner. Resour. Eng., vol. 10, no. 4, pp. 397-413, 2001.

[4] P. Tschakert, "Recognizing and nurturing artisanal mining as a viable livelihood," Resour. Policy, vol. 34, no. 1-2, pp. 24-31, 2009.

[5] C. Machado and J. Paulo Davim, "Management for sustainable development," Manag. Sustain. Dev., vol. 45, pp. 1-188, 2016. 
[6] G. Hilson, "A contextual review of the Ghanaian small-scale mining industry," Mining, Miner. Sustain. Dev., no. 76, p. 29, 2001.

[7] B. Staatsen et al., "Exploring triple-win solutions for living, moving and consuming that encourage behavioural change, protect the environment, promote health and health equity," -, vol., no., p. , 2017.

[8] E. Mejia, P. Pacheco, A. Muzo, and B. Torres, "Smallholders and timber extraction in the Ecuadorian Amazon: amidst market opportunities and regulatory constraints," Int. For. Rev., vol. 17, no. 1, pp. 38-50, 2015.

[9] L. Mancini and S. Sala, "Social impact assessment in the mining sector: Review and comparison of indicators frameworks," Resour. Policy, vol. 57, no. January, pp. 98-111, 2018.

[10] A. Leontine and D. Chou, "Global, regional, and national levels and trends in maternal mortality," Lancet, 2016.

[11] Y. Cai and D. Newth, "Oil, Gas and Conflict: A Mathematical Model for the Resource Curse," PLoS One, vol. 8, no. 6, 2013.

[12] S. Boadi, C. A. Nsor, O. O. Antobre, and E. Acquah, "An analysis of illegal mining on the Offin shelterbelt forest reserve, Ghana: Implications on community livelihood," J. Sustain. Min., vol. 15, no. 3, pp. 115-119, 2016.

[13] G. Hilson and C. Garforth, “Everyone Now is Concentrating on the Mining': Drivers and Implications of Rural Economic Transition in the Eastern Region of Ghana," J. Dev. Stud., vol. 49, no. 3, pp. 348-364, 2013.

[14] H. Hausermann et al., "Land-grabbing, land-use transformation and social differentiation: Deconstructing 'small-scale' in Ghana's recent gold rush," World Dev., vol. 108, pp. 103-114, 2018.

[15] S. Al-Hassan and R. Amoako, "Environmental and security aspects of contemporary small scale mining in Ghana," 3rd UMaT Bienn. Int. Min. Miner. Conf., p. 146, 2014.

[16] A. W. Moomen, M. Bertolotto, P. Lacroix, and D. Jensen, "Inadequate adaptation of geospatial information for sustainable mining towards agenda 2030 sustainable development goals," J. Clean. Prod., vol. 238, p. 117954, 2019.

[17] United Nations, Brundtland Commission Report | Our Common Future. 1987.

[18] M. Tost, V. Chandurkar, M. Hitch, P. Moser, and S. Feiel, "Is it time for a Global Mining Initiative 2.0?," 2017.

[19] D. Reay, C. Sabine, P. Smith, and G. Hymus, Intergovernmental Panel on Climate Change. Fourth Assessment Report. Geneva, Switzerland: Inter-gov- ernmental Panel on Climate Change. Cambridge; UK: Cambridge University Press; 2007. Available from: www. ipcc.ch. 2007.

[20] M. Pouliot and T. Treue, "Rural People's Reliance on Forests and the Non-Forest Environment in West Africa: Evidence from Ghana and Burkina Faso," World Dev., vol. 43, no. June 2011, pp. 180-193, 2013.

[21] T. F. G. Insaidoo, M. A. F. Ros-tonen, L. Hoogenbosch, and E. Acheampong, "Addressing forest degradation and timber deficits in Ghana," ETFRN News, vol. 53, no. December 2014, pp. 230$239,2012$.

[22] S. M. Banchirigah, "Challenges with eradicating illegal mining in Ghana: A perspective from the grassroots," Resour. Policy, vol. 33, no. 1, pp. 29-38, 2008.

[23] G. Hilson and C. Potter, "Why is illegal gold mining activity so ubiquitous throughout rural Ghana? African Development Revue 15 (2), 237-270.,” pp. 237-270, 2003.

[24] P. Tschakert and K. Singha, “Contaminated identities: Mercury and marginalization in Ghana's artisanal mining sector,” Geoforum, vol. 38, no. 6, pp. 1304-1321, 2007. 
[25] J. Bebbington, C. Larrinaga-González, and J. M. Moneva-Abadía, "Legitimating reputation/the reputation of legitimacy theory," Accounting, Audit. Account. J., vol. 21, no. 3, pp. 371-374, 2008.

[26] I. Scoones, "Livelihoods perspectives and rural development," J. Peasant Stud., vol. 36, no. 1, pp. 171-196, 2009.

[27] C. Vasco, B. Torres, P. Pacheco, and V. Griess, "The socioeconomic determinants of legal and illegal smallholder logging: Evidence from the Ecuadorian Amazon," For. Policy Econ., vol. 78, pp. 133-140, 2017.

[28] A. de Sherbinin et al., "Rural household demographics, livelihoods and the environment," Glob. Environ. Chang., vol. 18, no. 1, pp. 38-53, 2008.

[29] D. Braja, "No Title, מצוטע עלון, vol. 66, pp. 37-39, 2012.

[30] M. Armstrong-Stassen, "Organisational practices and the post-retirement employment experience of older workers," Hum. Resour. Manag. J., vol. 18, no. 1, pp. 36-53, 2008.

[31] A. Novara, A. Armstrong, L. Gristina, K. T. Semple, and J. N. Quinton, "Effects of soil compaction, rain exposure and their interaction on soil carbon dioxide emission," Earth Surf. Process. Landforms, vol. 37, no. 9, pp. 994-999, 2012.

[32] L. Miranda-Aragón et al., "Modeling susceptibility to deforestation of remaining ecosystems in North Central Mexico with logistic regression," J. For. Res., vol. 23, no. 3, pp. 345-354, 2012.

[33] J. P. Rud, "Electricity provision and industrial development: Evidence from India," Elsevier B.V., 2012.

[34] T. Akabzaa and A. Darimani, "Impact of mining sector investment in Ghana: A study of the Tarkwa mining region. A draft report prepared for SAPRI," 2001.

[35] M. A. Yeboah, "Porters provide important and useful services to their clients but their strategies expose them to vulnerabil- ity and exclusion in the city . Unfortunately, little research and attention has targeted this poor group and no specific policies have been im," vol. 56, no. 3, pp. 42-60, 2010.

[36] O. Jonathan and A. Isaac, "Environmental and rural livelihoods implications of small-scale gold mining in Talensi-Nabdam Districts in Northern Ghana," J. Geogr. Reg. Plan., vol. 7, no. 8, pp. 150-159, 2014.

[37] F. Hayes, K., \& Wagner, "Artisanal \& small-scale mining and livelihoods in Africa.," 20th Annual Meeting of the Governing Council of the Common Fund for Commodities. Tanzania. .

[38] M. Tost, M. Hitch, V. Chandurkar, P. Moser, and S. Feiel, "The state of environmental sustainability considerations in mining," J. Clean. Prod., vol. 182, pp. 969-977, 2018.

[39] A. J. Nightingale, T. Böhler, B. Campbell, and L. Karlsson, Environment and sustainability in a globalizing world. 2019.

[40] I. ICMM, "Sustainable development framework," International Council on mining and metals, pp. 2-17, 2003.

[41] J. Jeswiet, "Including Towards Sustainable Mining in Evaluating Mining Impacts," Procedia CIRP, vol. 62, pp. 494-499, 2017.

[42] G. Lamberton, "Sustainability accounting - A brief history and conceptual framework," Account. Forum, vol. 29, no. 1, pp. 7-26, 2005.

[43] J. P. Schöggl, M. M. C. Fritz, and R. J. Baumgartner, "Toward supply chain-wide sustainability assessment: A conceptual framework and an aggregation method to assess supply chain performance," J. Clean. Prod., vol. 131, pp. 822-835, 2016.

[44] N. Yakovleva, Corporate Social Responsibility in the Mining Industries. London: Routledge, 2005.

[45] J. Dubiński, "Sustainable Development of Mining Mineral Resources," J. Sustain. Min., vol. 12, no. 1, pp. 1-6, 2013. 
[46] G. Hilson, C. J. Hilson, and S. Pardie, "Improving awareness of mercury pollution in small-scale gold mining communities: Challenges and ways forward in rural Ghana," Environ. Res., vol. 103, no. 2, pp. 275-287, 2007.

[47] H. Sahu, "Land Degradation due to Mining in India and its Mitigation Measures Land," no. October, pp. 1-5, 2014.

[48] D. Owusu-Koranteng, "Mining investment \& community struggles," Rev. Afr. Polit. Econ., vol. 35, no. 117 , pp. 467-473, 2008.

[49] A. B. Yirenkyi-Fianko, "Impact of Artisanal and Small-scale Mining on the Environment in Ghana.," Essays Land, Ecotheology, Tradit. Africa, p. 135, 2019.

[50] J. Di John, “The ' Resource Curse ': Theory and Evidence ( ARI ),” Sc, no. 1999, pp. 17-18, 2010.

[51] S. Siegel and M. M. Veiga, "Artisanal and small-scale mining as an extralegal economy: De Soto and the redefinition of 'formalization,"' Resour. Policy, vol. 34, no. 1-2, pp. 51-56, 2009.

[52] M. E. Porter and C. Van Der Linde, "Toward a new conception of the environment-competitiveness relationship," Corp. Environ. Responsib., vol. 9, no. 4, pp. 61-82, 2017.

[53] R. T. Deacon and A. Rode, "Rent seeking and the resource curse," Companion to Polit. Econ. Rent Seek., no. 2002, pp. 227-247, 2014.

[54] R. T. Deacon, "The political economy of the natural resource curse: A survey of theory and evidence," Found. Trends Microeconomics, vol. 7, no. 2, pp. 111-208, 2012.

[55] S. A. Shehu, M. A. Jethro, D. A. Ogbodo, and M. H. M. Hashim, "Correlation of blasting coefficient with drilling rate of rocks," Mater. Today Proc., vol. 17, pp. 543-552, 2019.

[56] S. Matabeleland, "The Effects of Artisanal Mining on Irrigation Farming The Case of Umzinyathini Irrigation Scheme in Umzingwane District ," vol. 10, no. 2, pp. 139-162.

[57] A. Koranteng, T. Zawila-Niedzwiecki, and I. Adu-poku, "Remote Sensing Study of Land Use / Cover Change in West Africa," J. Environ. Prot. Sustain. Dev., vol. 2, no. 3, pp. 17-31, 2016.

[58] K. M. Albert, "Role of revegetation in restoring fertility of degraded mined soils in Ghana: A review," Int. J. Biodivers. Conserv., vol. 7, no. 2, pp. 57-80, 2015.

[59] J. Campbell and A. Deaton, “Consumption So Smooth ?," no. September, pp. 357-373, 2017.

[60] D. Krueger, "Does Income Inequality Lead to Evidence Consumption Inequality? and Theory," vol. 73, no. 1, pp. 163-193, 2013.

[61] G. Angeletos, D. Laibson, A. Repetto, J. Tobacman, and S. Weinberg, "The Hyperbolic Consumption Model :," J. Econ. Perspect., vol. 15, no. 3, pp. 47-68, 2001.

[62] B. A. Teschner, "Small-scale mining in Ghana: The government and the galamsey," Resour. Policy, vol. 37, no. 3, pp. 308-314, 2012.

[63] N. Gyimah, "Impact of Galamsey Operations on Agricultural Land and Livelihood of Farmers: A Case Study of Affiena Community in Wassa Amenfi West District of Western Region, Ghana," SSRN Electron. J., 2019.

[64] Ghana Statistical Service, “2010 population and Housing Census:Regional Analytical Report(Vol.1)," Accra, 2013.

[65] K. T. Hau and H. W. Marsh, "The use of item parcels in structural equation modelling: Non-normal data and small sample sizes," Br. J. Math. Stat. Psychol., vol. 57, no. 2, pp. 327-351, 2004.

[66] V. Vivoda and D. Kemp, "How do national mining industry associations compare on sustainable development?," Extr. Ind. Soc., vol. 6, no. 1, pp. 22-28, 2019.

[67] J. W. van Prooijen and W. A. van der Kloot, "Confirmatory analysis of exploratively obtained factor structures," Educ. Psychol. Meas., vol. 61, no. 5, pp. 777-792, 2001. 